\title{
The Impact of the COVID-19 Pandemic on One of The Biggest Technology Giant Shares: A Financial Analysis on Microsoft Corporation
}

\author{
Romina Barrantes ${ }^{1}$ and Thomas Leach\# \\ ${ }^{1}$ Colegio Franklin Delano Roosevelt, The American School of Lima, Lima, Peru \\ \#Advisor
}

ABSTRACT

Big technology stocks have been on a roll since April 2020, escaping the consequences of the coronavirus outbreak. The coronavirus pandemic created a vast tailwind for technology giants, especially Microsoft by inciting shifts in the corporations' behavior which are currently outliving the health crisis. The financial analysis on this firm aimed to develop a thorough analysis centered on its corporate history, market summary, financial statements (income statements, balance sheets, cash flows statements), normalized financial statements (normalized income statement, normalized balance sheet, and normalized statement of cash flows), stock valuation, SWOT analysis, and major competitors' performance. The aim of the evaluation is to get enough information to construct a thorough evaluation concerning the company's performance and analyze the effects of the coronavirus pandemic on the company. The evaluation indicated this giant technology company is booming during the pandemic even when the global economy is in a recessionary gap. The financial analysis may suggest further research into.

\section{Overview}

Microsoft Corporation is a technology company whose mission is to empower every person and every organization on the planet to achieve more. The corporation strives to create local opportunity growth, and impact in every country worldwide. The organization's platforms and tools help conduct small business productivity, large business competitiveness, and public-sector efficiency. These platforms and tools support startups, improve educational and health outcomes, and empower human ingenuity. Since the coronavirus outbreak, the organization is aiming to ensure the safety of its employees, striving to protect the health and well-being of the communities in which the business operates, and providing the necessary technology and resources to potential customers in the coronavirus pandemic.

The corporation continues to transform the business to lead in the new era of the intelligent cloud and intelligent edge, bringing technology and products together into experiences and solutions that unlock value for their customers. Microsoft Corporation's role as a platform and tool provider allows customers to bring together an ecosystem of partners, and enable organizations of all sizes to construct the necessary digital capability in order to address the upcoming challenges. Since its foundation, Microsoft Corporation has developed and supported software, services, devices, and solutions which deliver new value for potential customers and help people and businesses achieve their potential.

The organization offers a variety of services, including cloud-based solutions that provide customers with software, services, platforms, and content, and provides solution support and consulting services; it delivers relevant online advertising to a global audience. The organization offers various products (operating systems; cross-device productivity applications; server applications; business solution applications; desktop and server management tools; 
as well as video games. Microsoft Corporation designs, manufactures, and sells devices (PCs, tablets, gaming and entertainment consoles, other intelligent devices, and related accessories).

\section{Corporate History}

In 1975, Bill Gates and Paul Allen officially founded Microsoft Corporation. In 1978, the company's first international office was officially founded in Japan, entitled "ASCII Microsoft". In 1980, The company signed a contract with IBM to develop an operating system for IBM's first personal computer. In 1981, IBM announced the release of the IBM Personal Computer, which became the dominant personal computer. In 1982, it formally launched its International Division and set up subsidiaries not only in Europe but worldwide; and Microsoft Corporation released Microsoft Flight Simulator version 1.0, marking one of the longest-running PC video game series. In 1983, Compaq releases its first PC-compatible machine with IBM compatible clones, which hurt IBM but helped Microsoft Corporation; Lotus Software releases Lotus 1-2-3, which is a spreadsheet program that becomes the IBM PC's first killer application that established the spreadsheet standard for the PC; and, Bill Gates introduces the first version of Microsoft Windows.

In 1984, Steve Jobs introduced the original Macintosh, the first mass-market computer with a graphical user interface. In 1985, Microsoft released Microsoft Excel, which will compete with, and later overtake, Lotus 1-2-3; Microsoft launches the first version of its Windows operating system, Windows 1.0, which runs on top of MS-DOS and has a primitive GUI. In 1986, Microsoft went public with an IPO, raising \$61 million at \$21 a share. In 1987, Microsoft released Windows 2.0. In 1990, Microsoft launched Windows 3.0 and released Microsoft Office, bundling together Microsoft Word, Microsoft Excel, and Microsoft PowerPoint. In 1991, Microsoft created Microsoft Research. In 1992, Microsoft released Windows 3.1. In 1993, Microsoft released Microsoft Encarta, the first digital multimedia encyclopedia; Microsoft released Windows NT 3.1, the first version of Windows available to business users. In 1994, Microsoft released Windows NT 3.5. In 1995, Microsoft released Windows NT 3.51, the last version of Windows to not have a Start Menu; Microsoft releases Windows 95, which features a new interface with a novel start button; and, Microsoft announces a partnership with NBC to create a new 24-hour cable news television station, MSNBC.

In 1997, Microsoft released Microsoft Office for Macintosh, ships Internet Explorer as the default browser for the Macintosh, and invests \$150 million in Apple. In 1998, Microsoft released Windows 98. In 1999, Microsoft released MSN Messenger, an IM client. In 2000, Microsoft released Windows ME. In 2001, Microsoft acquired Ensemble Studios; and, Microsoft released Windows XP. In 2002, Microsoft launched the NET initiative, which creates an entirely new API for Windows programming and includes a new programming language. In 2003, Microsoft announced Windows Mobile. In 2006, Microsoft launched adCenter, an online advertising service that provides payper-click advertising. In 2007, Microsoft released Windows Vista to the general public and was made available for purchase and download from Microsoft's website. In 2009, Microsoft launched Windows 7 to the general public; and, Microsoft unveiled Microsoft Bing, a search engine to replace MSN. In 2010, Microsoft launched Microsoft Azure; and, Microsoft announced Windows Phone, a family of mobile operating systems as the replacement successor to Windows Mobile.

In 2011, Microsoft acquired Skype for \$8.5 billion. In 2012, Microsoft launched Microsoft Surface, a series of Windows-based personal computing devices designed and manufactured by Microsoft under its hardware division. In 2013, Microsoft acquired Nokia in an attempt to expand its presence in mobile. In 2014, Microsoft announced Cortana, an intelligent personal assistant; and finally, the Windows Insider program was announced, allowing users to test Windows 10 and provide feedback to Microsoft developers. In 2015, Microsoft released Windows 10, which acts as a "universal" application architecture across multiple Microsoft product families. In 2016, Microsoft announced to buy SwiftKey, a startup based out of London that makes keyboard apps for Android and iOS devices; Microsoft announces to buy Xamarin, a company that allows developers to build fully native apps across several platforms from a single shared codebase; Microsoft announces the acquisition of LinkedIn at $\$ 26.2$ billion ( $\$ 60$ per user); the Surface 
Studio and Surface Dial are announced; and Microsoft Teams, a cloud-based team collaboration tool, is launched as part of Office 365. In 2019, Microsoft released a new version of Microsoft Edge. A new logo of Microsoft Edge was introduced. In 2020, the company announced the beta version of Windows 10X and announced that all stores will be closed due to the pandemic.

\section{Market Summary}

\begin{tabular}{|c|c|c|c|}
\hline \multicolumn{4}{|c|}{ Microsoft Corporation (MSFT) } \\
\hline \multicolumn{4}{|c|}{ NasdaqGS - NasdaqGS Real Time Price. Currency in USD } \\
\hline \multicolumn{4}{|c|}{$231.96-6.97(-2.92 \%)$} \\
\hline \multicolumn{4}{|c|}{ At close: January 29 4:00 est } \\
\hline Previous Close & 238.93 & Market Cap & $1.749 \mathrm{~T}$ \\
\hline Open & 235.99 & Beta (5Y Monthly) & 0.83 \\
\hline Bid & $231.67 \times 800$ & PE Ratio (TTM) & 34.58 \\
\hline Ask & $231.80 \times 800$ & EPS (TTM) & 6.71 \\
\hline Day's Range & $231.36-238.01$ & Earnings Date & April 27, 2021 - May 03, 2021 \\
\hline 52 Week Range & $132.52-242.64$ & Forward Dividend Date \& Yield & $2.24(0.94 \%)$ \\
\hline Volume & $40,004,239$ & Ex-Dividend Date & Feb 17, 2021 \\
\hline Avg.Volume & $29,713,472$ & 1y Target Est & 270.80 \\
\hline
\end{tabular}

Figure 1: Microsoft Corporation Corporate Summary (data from yahoo finance)

Microsoft Corporation's previous close shows that the last price reported as traded in a one-day time frame is \$238.93, while the opening price shows that the price at which the organization's security initially trades when an exchange opens during a one-day time frame is $\$ 235.99$. The bid, representing the highest price a buyer (investor, trader, or dealer) is willing to pay for the security is valued at $\$ 231.67 \times 800$. While, the ask, representing the lowest price a seller is willing to accept for the security is valued at $\$ 231.80 \times 800$. Concerning the bid-ask spread, the difference between the highest price the buyer (investor, trader, or dealer) is willing to pay for the security and the lowest price the seller is willing to accept for it is valued at \$ 104. Thus, the organization is a liquid stock since the security is easily and quickly sold or exchanged for cash without a substantial loss in value, and as a result, being of lower risk for buyers (investors, traders, or dealers).

Concerning the day's range, the difference between both high and low prices in a one-day time period is valued from $\$ 231.36$ - \$238.01. Because volatility is equivalent to risk, the security's trading range with small price fluctuations indicates that there is less risk in investing in the organization. Concerning the 52-week range, the highest and lowest published prices of the security over the previous year are \$242.64 and \$132.52, respectively. Concerning the volume, the number of shares of the security traded during the one-day time period is 40004239 , meaning there is higher liquidity, better order execution, and a more active market for connecting a buyer and seller. Regarding the average volume, 29713472 shares are traded per day. As for the market cap, according to the stock market, the company is worth 1479000000 000. Further, Microsoft Corporation is a large-cap company, which makes it a major player in well-established industries. Though this company might not necessarily bring in huge returns in a short period of time, over the long run, it is likely to reward investors with a consistent increase in share value and dividend payments.

Regarding the beta (5Y monthly), the volatility of the organization's stock compared to the systematic risk of the entire market is 0.83 , meaning that the security is theoretically less volatile than the market. As for the P/E ratio (TTM), the relation of the company's share price to its earnings per share is 34.58 , meaning that the stock's price is relative to earnings (as the current market value of the company is equal to 34.58 times its annual earnings) and possibly overvalued. As Microsoft Corporation is a company that is growing faster than average, it has a higher P/E, 
showing investors are willing to pay a higher share price today due to growth expectations in the future. Considering the average P/E for the S\&P 500 ranges from 13 to 15 , Microsoft Corporation with a current $\mathrm{P} / \mathrm{E}$ of 34.58 , above the S\&P average, trades at 34.58 times earnings. This high multiple indicates that investors expect a higher growth from the company compared to the overall market.

Concerning the EPS (TTM), for each share of its stock, the company is making \$ 6.71, meaning investors will be willing to pay a consistent amount of money for the company's shares since the EPS value indicates the company is likely to bring consistent profits relative to its share price. Concerning the earnings date, the date of the next release of the company's financial report is around April 27, 2021 - May 23, 2021. Concerning the forward dividend and yield, the percentage of the company's current stock price that it expects to pay out as dividends over a 12-month time period is $0.94 \%$. Concerning the ex-dividend date, the day on which a stock begins trading without the subsequent dividend value is on February 27, 2021, meaning that investors who purchased the stock before the ex-dividend date are entitled to the next dividend payment while those who purchased the stock either on the ex-dividend date or after are not. Concerning the $1 \mathrm{Y}$ Target Estimate, the price that financial analysts have predicted the stock will be one year from now is $\$ 270.78$.

\section{Financial Analysis}

\section{Income Statement:}

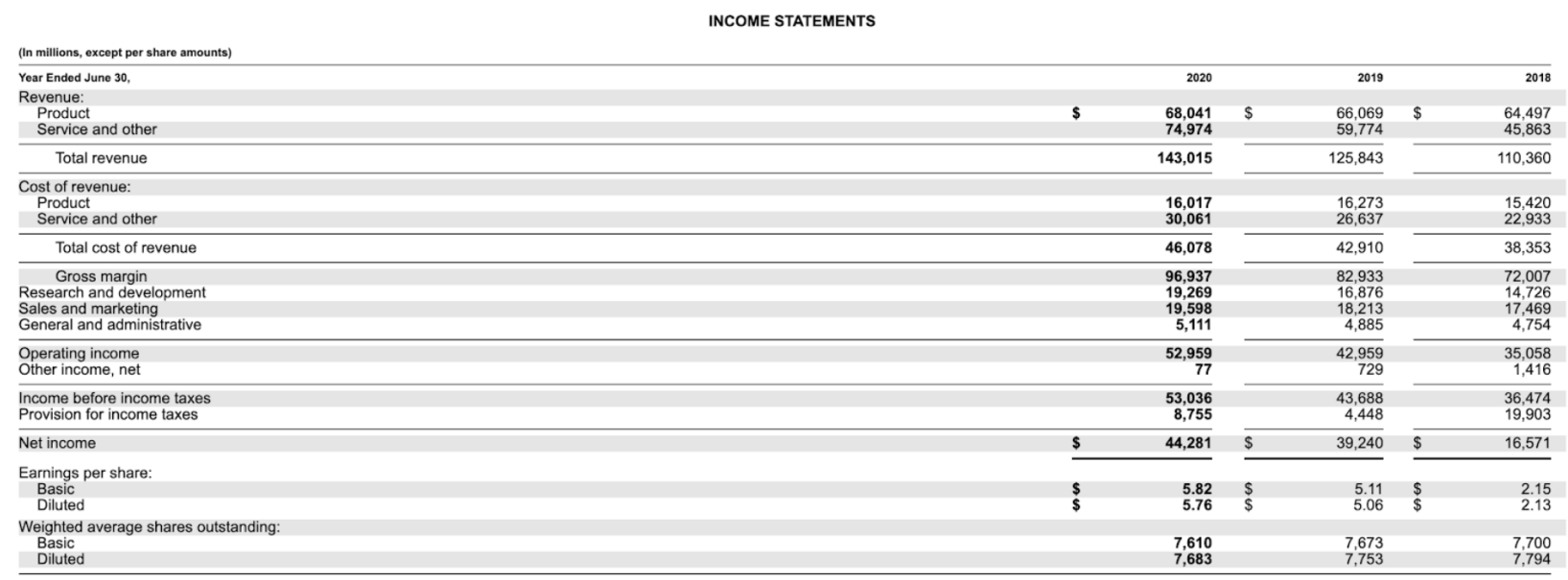

Figure 2: Microsoft Corporation's Income Statement

As for the revenue growth, from 2018-19, the income received from normal business operations and other business activities increased by $14.0 \%$ from \$ 110360 million to \$ 125843 million, and from 2019-20, the income received from normal business operations and other business activities increased by $13.6 \%$ from $\$ 125843$ million to $\$ 143015$ million. Therefore, from 2018-20, the income received from normal business operations and other business activities increased by $29.6 \%$ from $\$ 110360$ million to $\$ 1430145$ million. Concerning the gross margin growth, from 2018-19, the company's gross margin increased by $15.2 \%$ from $\$ 72007$ to $\$ 82933$, and from 2019-20, the company's gross margin increased by $16.9 \%$ from $\$ 82933$ to $\$ 96937$. Therefore, from 2018-20, the company's gross margin increased by $34.6 \%$ from $\$ 72007$ to $\$ 96937$, meaning that the profit the company makes after deducting the costs associated with making and selling its products and the costs associated with providing its services increased by $34.6 \%$, and it increased its efficiency at using its labor and supplies in producing goods or services by the same percentage.

Regarding the gross profit margin, in 2018, the gross profit margin percentage was $65.2 \%$ (because [110 360 million - 38353 million] / [110 360 million] = 0.652), in 2019, the gross profit margin percentage was $65.9 \%$ (because 
[125 843 million - 42910 million] / [125 843 million] = 0.659), and in 2020, the gross profit margin percentage was $67.8 \%$ (because [143 015 million - 46078 million] / [143 015 million] $=0.678$ ). Making a strong emphasis on the gross profit margin growth, from 2018-19, the company's gross profit margin increased by $0.70 \%$ from $65.2 \%$ to $65.9 \%$, and from 2019-20, the company's gross profit margin increased by $1.90 \%$ from $65.9 \%$ to $67.8 \%$. Therefore, from 2018-20, the company's gross profit margin increased by $2.6 \%$ from $65.2 \%$ to $67.8 \%$, meaning the company is less successfully producing profit over and above its costs and, as a result, became less profitable within this time period. Concerning the operating income growth, from 2018-19, the company's operating income increased by 22.5 $\%$ from \$ 35058 million to \$ 42959 million, and from 2019-20, the company's operating income increased by 23.3 $\%$ from $\$ 42959$ million to $\$ 52959$ million. Therefore, from 2018-20, the company's operating income increased by $51.1 \%$ from $\$ 35058$ million to \$ 52959 million, meaning the company's management is generating more revenue while controlling expenses, production costs, and overhead.

Concerning net income growth, from 2018-19, the company's net income increased by $137 \%$ from $\$ 16571$ million to \$ 39240 million, and from 2019-20, the company's net income increased by $12.8 \%$ from \$39240 million to $\$ 44281$ million. Therefore, from 2018-20, the company's net income increased by $167 \%$ from $\$ 16571$ million to \$ 44281 million, meaning that the company's net income or bottom line, showing the excess of expenses and losses over revenues and gains increased by $167 \%$. Concerning the basic earnings per share growth, from 2018-19, the company's basic earnings per share increased by $138 \%$ from $\$ 2.15$ to $\$ 5.11$, and from $2019-20$, the company's basic earnings per share increased by $13.9 \%$ from $\$ 5.11$ to $\$ 5.82$. Hence, from 2018-20, the company's earnings per share increased by $171 \%$ from $\$ 2.15$ to $\$ 5.82$, meaning the company's amount of profit allocated to one share of its common stock increased by $171 \%$ from $\$ 2.15$ to $\$ 5.82$. Concerning the diluted earnings per share growth, from 2018-19, the company's diluted earnings per share increased by $138 \%$ from $\$ 2.13$ to $\$ 5.06$, and from $2019-20$, the company's diluted earnings per share increased by $\% 13.8$ from $\$ 5.06$ to $\$ 5.76$. Thus, from 2018-20, the company's diluted earnings per share increased by $170 \%$ from $\$ 2.13$ to $\$ 5.76$, meaning that the company's earnings per share if convertible securities were converted increased by $170 \%$ from $\$ 2.13$ to $\$ 5.76$.

\section{Balance Sheet:}

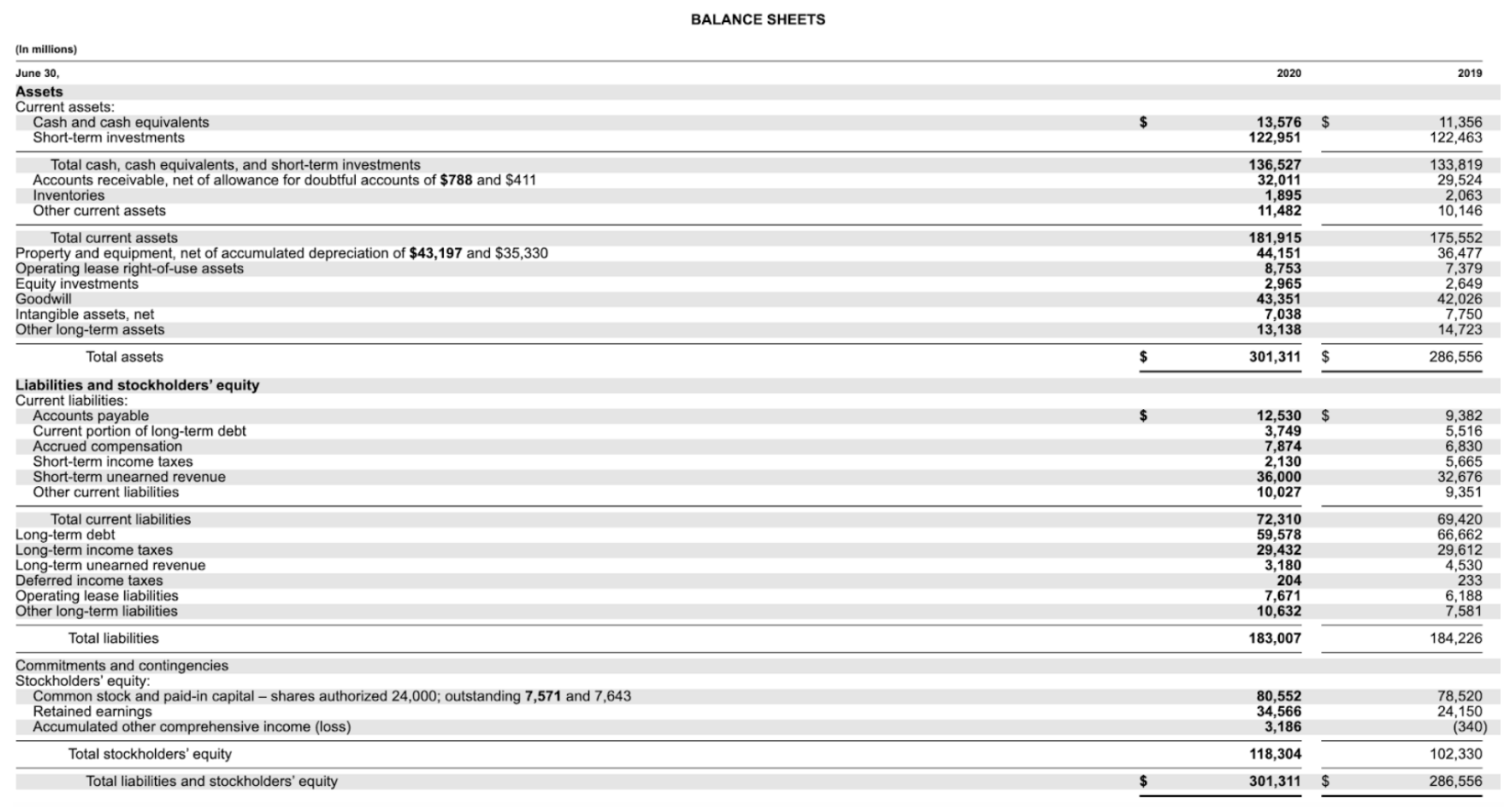

Figure 3: Microsoft Corporation's Balance Sheet 
As for the cash and cash equivalents growth, from 2019-20, the company's cash and cash equivalents increased by $19.5 \%$ from \$ 11356 million to \$ 13576 million, meaning that the company's value of assets that are cash or can be converted into cash in the short-term acquired higher liquidity due to an increase of $19.5 \%$ from $\$ 11356$ million to \$ 13576 million. Therefore, the company possesses less risk, and, as a result, receives a lower interest rate that translates into higher profitability. Concerning total assets growth, from 2019-20, the company's total assets increased by $5.15 \%$ from $\$ 286556$ million to $\$ 301311$ million, meaning that the company's total liabilities and equity increased by $5.15 \%$ from \$ 286556 million to \$ 301311 million. Therefore, the company's increase in total assets indicates that the company's total liabilities and equity have increased by the same quantity, and as a result, an increase in total assets highlights the company's growth.

Regarding the accounts payable, from 2019-20, the company's accounts payable increased by $33.6 \%$ from $\$$ 9382 million to \$ 12530 million. Therefore, the company is buying more goods and services on credit, rather than paying cash. Concerning the total current liabilities, employing the current ratio, which measures the company's ability to pay its short-term financial debts or obligations, in 2019, the current ratio is 2.53 [because \$175 552 million / \$ 69 420 million $=2.53$ ], and in 2020, the current ratio is 2.52 [because $\$ 181915$ million $/ \$ 72310$ million $=2.52$ ]. Since the current ratios of 2.53 (in 2019) and 2.52 (in 2020) are higher than 1, these are considered ideal since these values demonstrate that there are more current assets to pay current short-term debts. However, it would not be convenient for the current ratios to reach a much higher number in the following years because the increase in current ratios would mean that the company is not leveraging its assets as well as it otherwise could be.

Concerning the total current liabilities growth, from 2019-20, the company's total current liabilities increased by $4.16 \%$ from $\$ 69420$ million to $\$ 72310$ million. Therefore, the company's short-term financial obligations (including accounts payable, short-term debt, dividends, notes payable, and income taxes owed) due within one year or within a normal operating cycle increased by $4.46 \%$ from \$ 69420 million to $\$ 72310$ million. As a result, the total current liabilities increase indicates that the company's accounts payable, accrued compensation, short-term unearned revenue, and other current liabilities increased, and suggests that cash flows from operations increased because we are referring to a use of cash. Concerning the total stockholders' equity growth, from 2019-20, the company's total stockholders' equity increased by \% 15.6 from \$ 102330 million to \$ 118304 million, meaning the company is becoming more profitable due to its rapid increase in revenue from $2019-20$ by $13.6 \%$ from $\$ 125843$ million to $\$ 143015$ million, and its slight increase of total cost of revenue from 2019-20 by $7.38 \%$ increase from \$ 42910 million to \$ 46078 million.

Since total revenue value and growth exceed the total cost of revenue value and growth, the business is generating more profit, driving up stockholders' equity as a result. Another reason for the total stockholders' equity increase by \% 15.6 from \$ 102330 million to \$ 118304 million to be carried out, occurred since the company sold additional shares of stock, evidenced by an increase in the number of common stock being traded in the stock market since, from 2019-20, the company's common stock and paid-in capital increased by $2.59 \%$ from $\$ 78520$ million to \$ 80552 million. The statement of the company selling additional assets is reinforced due to the increase in the company's total assets from 2019-20 by $5.15 \%$ from \$ 286556 million to \$ 301311 million. Selling stocks not only raises the value of total stockholders' equity but also brings in new shareholders who are willing and able to share in the company's equity. The last reason for the total stockholders' equity increase by \% 15.6 from $\$ 102330$ million to $\$ 118304$ million to be carried out, occurred due to an increase in the company's retained earnings from $2019-20$ by $43.1 \%$ from \$ 24150 million to \$ 34566 million. Hence, the company's retained earnings, including cash reserves and money spent in order for the company to acquire new assets as well as money to pay off debt, is one of the most prominent factors directly increasing stockholders' equity.

Concerning the total liabilities and stockholders' equity growth, from 2019-20, the company's total liabilities and stockholders' equity increased by $5.15 \%$ from \$ 286556 million to \$ 301311 million, meaning that since total liabilities are part of the company's total debt and equity is the capital that the company has raised, assets are bought out of the total liabilities and equity for the operating activities of the company. This is indicating that assets are balanced by total liabilities and equity. 


\section{Income Statement and Balance Sheet:}

Concerning the return on equity (ROE), in 2019, the company's return on equity (ROE) was $38.3 \%$ [because $39240 / 102330=0.383$ ], and in 2020, the company's return on equity (ROE) was $37.4 \%$ [because $44281 / 118304$ $=0.374]$. Therefore, considering the return on equity (ROE) near the long-term average of $14 \%$ as an acceptable ratio and below $10 \%$ as a poor ratio, in 2019, the company's return on equity (ROE) was more than acceptable since its percentage (38.3\%) exceeded the long-term average ratio of $14 \%$ by $24.3 \%$, and in 2020 , the company's return on equity (ROE) was more than acceptable since its percentage (37.4\%) exceeded the long-term average ratio of $14 \%$ by $23.4 \%$. As a result, in 2019 and 2020, the company was profitable in terms of stockholders' equity.

Concerning the return on assets (ROA), in 2019, the company's return on assets (ROA) was $13.7 \%$ [because $39240 / 286556=0.130$ ], and in 2020, the company's return on assets (ROA) was $14.7 \%$ [because $44281 / 301311$ $=0.147]$. Therefore, considering that an increasing return on assets (ROA) indicates that the company is good at converting its investments into profits, the company's return on assets' upward trend indicates that the company is continuing to earn an increasing profit on each dollar of investment. The company's positive return on assets (ROA) indicates it can effectively use its assets to generate income.

\section{Cash Flows Statement:}

CASH FLOWS STATEMENTS

\begin{tabular}{|c|c|c|c|c|c|}
\hline Year Ended June 30, & & 2020 & & 2019 & 2018 \\
\hline $\begin{array}{l}\text { Operations } \\
\text { Net income }\end{array}$ & $\$$ & 44,281 & $\$$ & 39,240 & 16,571 \\
\hline Adjustments to reconcile net income to net cash from operations: & & & & 11682 & \\
\hline $\begin{array}{l}\text { Depreciation, amortization, and other } \\
\text { Stock-based compensation expense }\end{array}$ & & 5,289 & & 4,652 & $\begin{array}{r}10,261 \\
3,940\end{array}$ \\
\hline $\begin{array}{l}\text { Net recognized gains on investments and derivatives } \\
\text { Deferred jincome taxes }\end{array}$ & & (219) & & & \\
\hline $\begin{array}{l}\text { Deferred income taxes } \\
\text { Changes in operating assets and liabilities: }\end{array}$ & & 11 & & $(6,463)$ & $(5,143)$ \\
\hline Accounts receivable & & $(2,577)$ & & $(2,812)$ & $(3,862)$ \\
\hline Inventories & & 168 & & 597 & (465) \\
\hline Other current assets & & $(2,330)$ & & $(1,718)$ & (952) \\
\hline Other long-term assets & & $(1,037)$ & & $(1,834)$ & $(285)$ \\
\hline Accounts payable & & 3,018 & & 232 & 1.148 \\
\hline $\begin{array}{l}\text { Unearned revenue } \\
\text { Incomet taxes }\end{array}$ & & 2,212 & & 4,462 & $\begin{array}{r}5,922 \\
18183\end{array}$ \\
\hline $\begin{array}{l}\text { Income taxes } \\
\text { Other current liabilities }\end{array}$ & & $\begin{array}{l}(3,631) \\
1,346\end{array}$ & & $\begin{array}{l}2,929 \\
1419\end{array}$ & 18,183 \\
\hline Other long-term liabilities & & 1,348 & & 591 & (20) \\
\hline Net cash from operations & & 60,675 & & 52,185 & 43,884 \\
\hline Financing & & & & & \\
\hline Repayments of short-term debt, maturities of 90 days or less, net & & 0 & & 0 & $(7,324)$ \\
\hline $\begin{array}{l}\text { Proceeds from issuance of debt } \\
\text { Cash premium on debt exchange }\end{array}$ & & $\begin{array}{r}0 \\
(3417)\end{array}$ & & 0 & $\begin{array}{r}7,183 \\
0\end{array}$ \\
\hline $\begin{array}{l}\text { Repayments of debt } \\
\text { Rexchange }\end{array}$ & & $\begin{array}{l}(3,417) \\
(5,518)\end{array}$ & & $(4,000)$ & $(10,060)$ \\
\hline Common stock issued & & 1,343 & & 1,142 & 1,002 \\
\hline Common stock repurchased & & $(22,968)$ & & $(19,543)$ & $(10,721)$ \\
\hline $\begin{array}{l}\text { Common stock cash dividends paid } \\
\text { Other, net }\end{array}$ & & $\begin{aligned}(15,137) \\
(334)\end{aligned}$ & & $\begin{aligned}(13,811) \\
(675)\end{aligned}$ & $\begin{array}{r}(12,699) \\
(971)\end{array}$ \\
\hline Net cash used in financing & & $(46.031)$ & & $(36887)$ & $(33,590)$ \\
\hline Investing & & & & & \\
\hline Additions to property and equipment & & $(15,441)$ & & $(13,925)$ & $(11,632)$ \\
\hline Acquisition of companies, net of cash acquired, and purchases of intangible and other assets & & $(2,521)$ & & $(2,388)$ & (888) \\
\hline Purchases of investments & & $(77,190)$ & & $(57,697)$ & $(137,380)$ \\
\hline Maturities of investments & & 66,449 & & 20,043 & 26,360 \\
\hline $\begin{array}{l}\text { Sales of investments } \\
\text { Other, net }\end{array}$ & & $\begin{array}{l}17,721 \\
(1,241)\end{array}$ & & 38,194 & $\begin{array}{c}117,577 \\
(98)\end{array}$ \\
\hline Net cash used in investing & & $(12,223)$ & & $(15,773)$ & $(6,061)$ \\
\hline Effect of foreign exchange rates on cash and cash equivalents & & (201) & & (115) & 50 \\
\hline $\begin{array}{l}\text { Net change in cash and cash equivalents } \\
\text { Cash and cash equivalents, beginning of period }\end{array}$ & & $\begin{array}{r}2,220 \\
11,356\end{array}$ & & $\begin{aligned}(590) \\
11,946\end{aligned}$ & $\begin{array}{l}4,283 \\
7,663\end{array}$ \\
\hline Cash and cash equivalents, end of period & $\$$ & 13.576 & $\$$ & 11,356 & 11,946 \\
\hline
\end{tabular}

Figure 4: Microsoft's Corporation Cash Flows Statement

Regarding the net cash from operations growth, from 2018-19, the company's net cash from operations increased by $18.9 \%$ from $\$ 43884$ million to $\$ 52185$ million, and from 2019-20, the company's net cash from operations increased by $16.3 \%$ from $\$ 52185$ million to $\$ 60675$ million. Therefore, from 2018-20, the company's net cash from operations increased by $38.3 \%$ from $\$ 43884$ million to $\$ 60675$ million, meaning that within this time period the company's sufficient positive cash flow generated to maintain and grow its operations increased by $38.3 \%$ from $\$ 43884$ million to $\$ 60675$ million. Since in 2018, 2019, and 2020, the bottom line is positive, more cash is being collected from customers than is spent on expenses. 
As for the net cash used in financing growth, from 2018-19, the company's net cash used in financing decreased by $9.82 \%$ from $\$-33590$ million to $\$-36887$ million, and from 2019-20, the company's net cash used in financing decreased by $24.8 \%$ from $\$-36887$ million to $\$-46031$ million. Hence, from 2018-20, the company's net cash used in financing decreased by $37.0 \%$ from $\$-33590$ million to $\$-46031$ million, meaning that in this time period, changes in long-term debt and changes in equity decreased by $37.0 \%$ from $\$-33590$ million to $\$-46031$ million. Negative cash provided by financing activities is highly desirable, especially coupled with positive operating cash flow. If the company experiences negative cash provided by financing activities, the company is paying back on long-term debt, purchasing treasury stock, or paying dividends. In this situation, the company is experiencing negative cash provided by financing activities from 2018-19, which means that it is paying back principal on long-term debt, purchasing either treasury stock, or paying dividends. Positive cash provided by financing activities indicates the company is borrowing more money long-term or issuing new shares of common stock. In this situation, cash provided by financing activities is not positive, indicating that the company is not borrowing money in the long term or issuing new shares of common stock.

Concerning the net cash used in investing growth, from 2018-19, the company's net cash used in investing decreased by $160 \%$ from $\$-6061$ million to $\$-15773$ million, and from 2019-20, the company's net cash used in investing increased by $22.5 \%$ from \$ - 15773 million to \$ - 12223 million. Therefore, from 2018-20, the company's net cash used in investing decreased by $102 \%$ from $\$-6061$ million to \$ - 12223 million, meaning that the amount of cash spent on investment-related activities decreased by $102 \%$ from \$ - 6061 million to \$ - 12223 million. Negative cash used in investing activities is highly desirable since it means the company is buying more property, plants, and equipment. In this case, since the company's net cash used in financing declined from 2018-20 by $102 \%$ from $\$-6$ 061 million to \$ - 12223 million, the company is buying more property, plant, and equipment.

Normalized Income Statement:

\begin{tabular}{|l|r|r|r|}
\hline Normalized to 2018 & 2020 & 2019 & 2018 \\
\hline Revenue & 1.30 & 1.14 & 1.00 \\
\hline Gross Margin & 1.35 & 1.15 & 1.00 \\
\hline Gross Profit Margin & 1.04 & 1.01 & 1.00 \\
\hline Operating Income & 1.51 & 1.23 & 1.00 \\
\hline Net Income & 2.67 & 2.37 & 1.00 \\
\hline
\end{tabular}

Figure 5: Microsoft Corporation's Normalized Income Statement (created in google spreadsheets)

According to the normalized income statement, from 2018-20, the firm's revenue approximately increased by 0.30 (or 30\%) from 1.00 to 1.30 ; its gross margin approximately increased by 0.35 (or $35 \%$ ) from 1.00 to 1.35 ; its gross profit margin approximately increased by 0.04 (or 4\%) from 1 to 1.04; its operating income approximately increased by 0.51 (or 51\%) from 1.00 to 1.51 ; and its net income increased by 1.67 or (167\%) from 1.00 to 2.67 . As a result, due to a consistent increase in these parameters, there was an improvement in the company's operations, the efficiency of its management, its under-performing sectors, and its financial performance from 2018-20. 
Normalized Balance Sheet:

\begin{tabular}{|l|r|r|}
\hline Normalized to 2019 & 2020 & 2019 \\
\hline Cash and cash equivalents & 1.19 & 1.00 \\
\hline Total assets & 1.05 & 1.00 \\
\hline Total current liabilities & 1.04 & 1.00 \\
\hline Total stockholders' equity & 1.16 & 1.00 \\
\hline Total liabilities and stockholders' equity & 1.05 & 1.00 \\
\hline
\end{tabular}

Figure 6: Microsoft Corporation's Normalized Income Statement (created in google spreadsheets)

According to the normalized balance sheet, from 2019-20, the cash and cash equivalents approximately increased by 0.19 (or 19\%) from 1.00 to 1.19 ; the total assets approximately increased by 0.05 (or $5 \%$ ) from 2019-20; the total current liabilities approximately increased by 0.04 (or 4\%) from 1.00 to 1.04 ; the total stockholders' equity approximately increased by 0.16 (or $16 \%$ ) from 1.00 to 1.16 ; the total liabilities and stockholders' equity approximately increased by 0.05 (or 5\%) from 1.00 to 1.05 . As a result, due to a consistent increase in these parameters, the state of the company's finances, its rates of return, and capital structure improved from 2019-20.

Normalized Cash Flows Statement:

\begin{tabular}{|l|r|r|r|}
\hline Normalized to 2018 & 2020 & 2019 & 2018 \\
\hline Net cash from operations & 1.38 & 1.19 & 1.00 \\
\hline Net cash used in financing & 1.37 & 1.10 & 1.00 \\
\hline Net cash used in investing & 2.02 & 2.60 & 1.00 \\
\hline
\end{tabular}

Figure 7: Microsoft Corporation's Normalized Cash Flows Statement (created in google spreadsheets - owner)

According to the normalized balance sheet, from 2018-20, the net cash from operations approximately increased by 0.38 (or 38\%) from 1.00 to 1.38 ; the net cash used in financing approximately increased by 0.37 (or $37 \%$ ) from 1.00 to 1.37 ; and, the net cash used in investing increased by 1.02 (or $102 \%$ ) from 1.00 to 2.02 . As a result, due to an increase in these parameters, the company's cash inflows from its ongoing operations and external investment sources improved from 2018-20. 


\section{SWOT Analysis:}

Table 1: SWOT Analysis on Microsoft Corporation

\begin{tabular}{|c|c|}
\hline Strenghts & Weaknesses \\
\hline $\begin{array}{l}\text { - Leader in the global market place in the cloud sector: Microsoft offers a wide array of } \\
\text { cloud-based computing services, which includes Bing, Microsoft Azure, Microsoft Dynamics } \\
\text { CRM Online, Microsoft Office } 365 \text {, One Drive, Skype, Xbox Live, as well as Yammer. In } 2018 \text {, } \\
\text { Microsoft had global datacenter footprint to } 54 \text { regions, which is more than other cloud provider } \\
\text { in the world. } \\
\text { - Effective leadership by Satva Nadella: One of the factors which set apart Microsoft from } \\
\text { competition. Since } 2014, \text { Nadella has been bold and effective in the company's restructuring and } \\
\text { reinvention. Initiatives, such as focusing Microsoff's mobile-based efforts and expanding plenty } \\
\text { of its services to be offered on other platforms like Mac by Satya Nadella proved to be effective } \\
\text { up to date. Leadership principles of Satya Nadella are based on the values of learning, choosing } \\
\text { to create a positive, impact, finding ways to innovate and making meaning a priority. } \\
\text { - Diversified product portfolio: Microsoff's portfolio of products and services is vast comprising } \\
\text { operating systems for computing devices, servers, phones, and other intelligent devices; server } \\
\text { applications for distributed computing environments; productivity applications; business solution } \\
\text { applications; desktop as well as server management tools; soffware development tools, video } \\
\text { games; as well as the online advertising. The company designs and sells hardware including } \\
\text { PCs, tablets, gaming and entertainment consoles, phones, other intelligent devices, as well as } \\
\text { related accessories. Its diversified portfolio protects and company against downturns in any } \\
\text { specific product or service segment. }\end{array}$ & $\begin{array}{l}\text { - Lack of innovation: Nowadays, people are still sitting on a huge installed base of old Windows } \\
\text { XP and Windows } 7 \text { computers. These customers seem to be happy even though Microsoft } \\
\text { virtually abandoned Windows XP, their most solid operating system ever. However, the key point } \\
\text { is that they are temporarily happy as "nothing on the market has shown them a good reason to } \\
\text { upgrade". } \\
\text { - } \quad \text { Loss of leadership position in the internet browser segment: Microsoft's Internet Explorer was a } \\
\text { leading browser application with market share of more than } 90 \% \text { for about two decades since } \\
\text { the beginning of } 1990 \text {. Nevertheless, Internet Explorer was quick to lose its market share since } \\
\text { the launch of Google Chrome in September } 2008 \text {. In } 2015 \text { the company launched Microsoft } \\
\text { Edge, a successor of Internet Explorer, but this browser is still far behind market leaders such as } \\
\text { Chrome, Safari and Firefox. } \\
\text { - Eailed acquisitions: A wide variety of Microsoff's acquisitions have been questionable. For } \\
\text { instance, Microsoft acquired Nokia for } \$ \text { billion at a time when Nokia had lost its entire market } \\
\text { share to Apple and Samsung. The company acquired Skype for } \$ 8 \text { billion and despite the } \\
\text { plattorm enjoying increased usage, Microsoft has not been able to make it financially viable. }\end{array}$ \\
\hline Opportunities & Threats \\
\hline $\begin{array}{l}\text { - Product affordability: Several Microsoft products have a notoriety for being overpriced, especially } \\
\text { when dealing with the low-cost or free alternatives. For instance, Microsoft Office costs } \$ 150 \text { for } \\
\text { a one-time installation while the open-source Apache OpenOffice provides the same software for } \\
\text { free. Therefore, by lowering prices or bundling services, Microsoft could increase market share } \\
\text { considerably. } \\
\text { - Smart acouisitions: Instead of acquiring businesses with less or no viability, Microsoft can use its } \\
\text { large cash reserves in order to acquire or form partnerships with innovative start-ups that bring a } \\
\text { different skill set and perspective to the company. } \\
\text { - Smartphone industry: The market of smartphones and tablets offer an excellent opportunity for } \\
\text { Microsoft to capitalize on the increasing demands of these products. }\end{array}$ & $\begin{array}{l}\text { - Changing consumer habits: With the limited presence in the mobile market and a consumer shift } \\
\text { away from PCs and laptops, Microsoft's reliance on operating systems is under direct threat. } \\
\text { - Counterfeit soffware: Low-quality imitation or counterfeit products are continuing to be a problem } \\
\text { for Microsoft, particularly in emerging and low-income markets. This is no doubt exacerbated by } \\
\text { Microsoft's high product prices and vulnerability to cybercrime. } \\
\text { - Changing preferences of consumers: Customers are highly attracted to the market of } \\
\text { smartphones, notepads, and laptops. However, Microsoft has modest shares in these markets. }\end{array}$ \\
\hline
\end{tabular}

\section{Major Competitors Performance:}

\section{Comparing Net Revenue:}

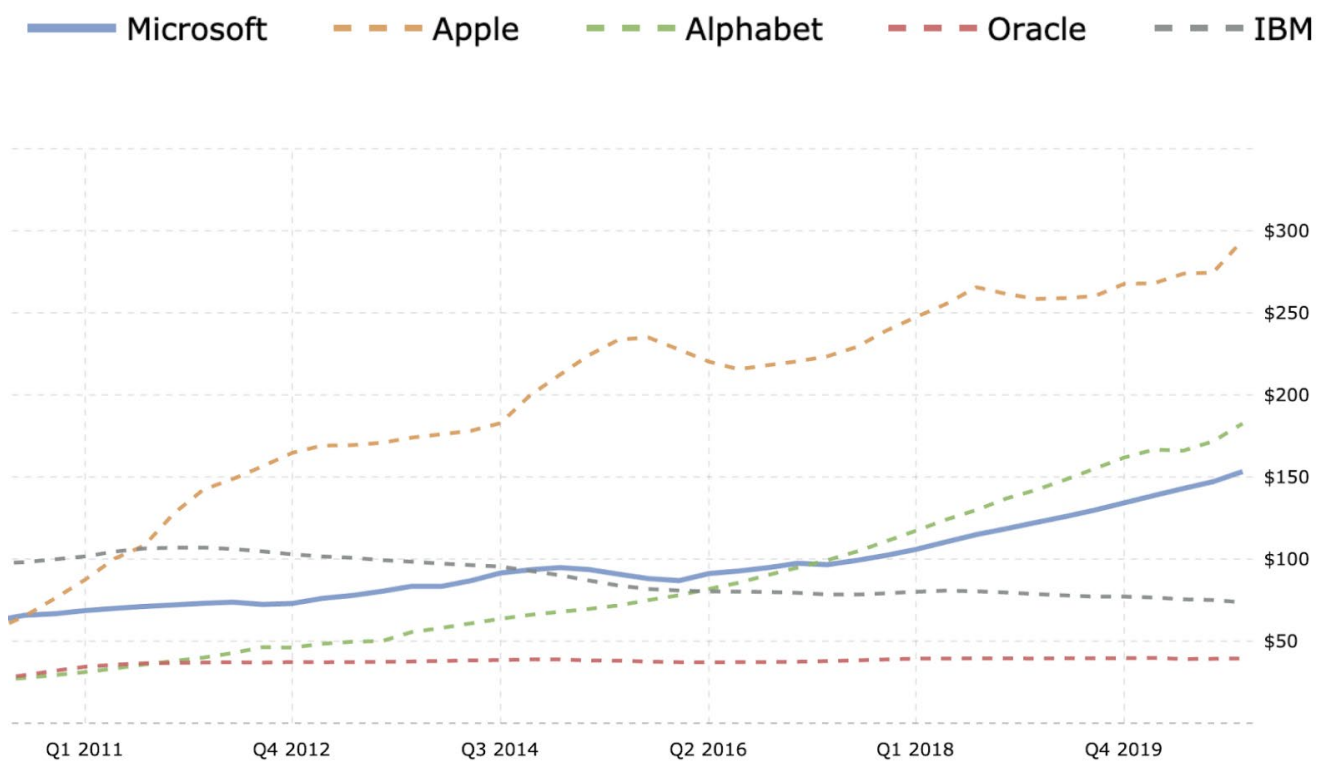

Figure 8: Microsoft Corporation's And Its Major Competitors' Net Revenue Growth (Graphical Representation) 
Table 2: Microsoft Corporation's And Its Major Competitors' Net Revenue Growth (Numerical Representation)

\begin{tabular}{|l|r|r|r|r|r|r|}
\hline Net Revenue (in billions) & 2016 Q1 & 2017 Q1 & 2018 Q1 & 2019 Q1 & 2020 Q1 & 2020 Q4 \\
\hline Microsoft & 86.89 & 97.41 & 105.88 & 122.21 & 267.98 & 153.28 \\
\hline Apple & 227.54 & 220.46 & 247.42 & 258.49 & 267.98 & 294.14 \\
\hline Alphabet & 77.99 & 94.77 & 117.25 & 142.01 & 166.68 & 182.53 \\
\hline Oracle & 37.16 & 37.43 & 39.33 & 39.38 & 39.77 & 39.40 \\
\hline IBM & 80.83 & 79.39 & 80.06 & 78.7 & 76.54 & 73.62 \\
\hline
\end{tabular}

\section{Comparing Net Income:}

Microsoft $\quad-=-$ Apple $\quad-=-$ Alphabet $\quad---$ Oracle $\quad---$ IBM

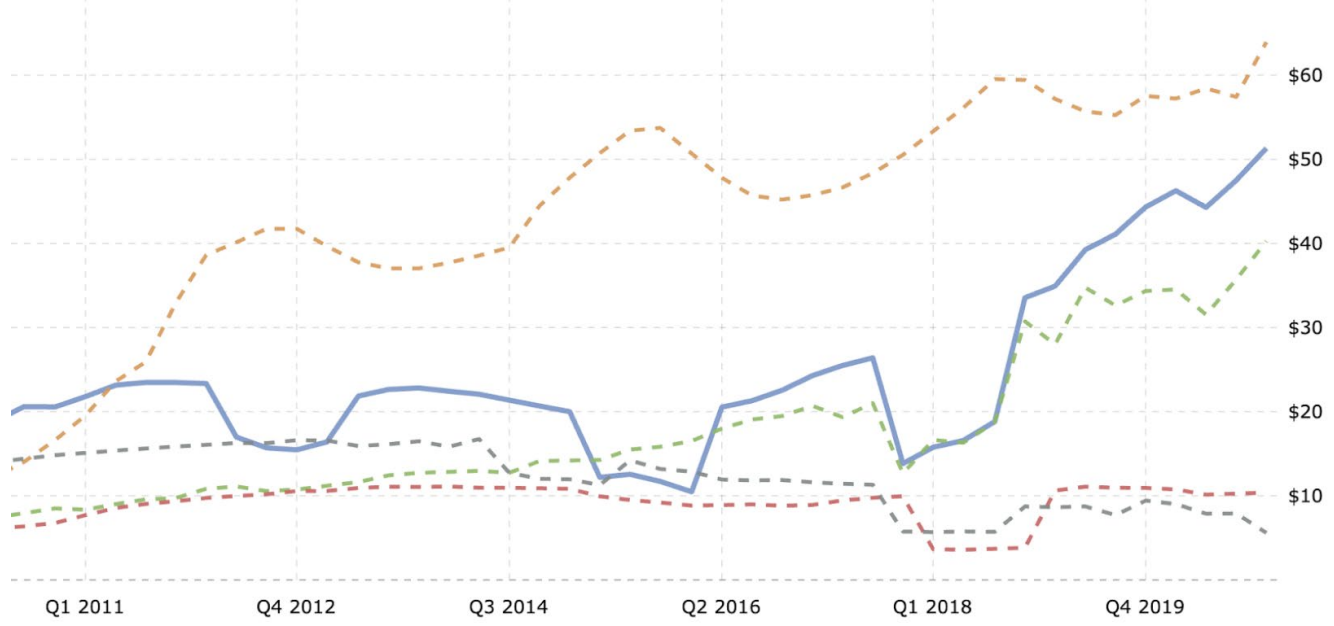

Figure 9: Microsoft Corporation's And Its Major Competitors' Net Income Growth (Graphical Representation)

Table 3: Microsoft Corporation's And Its Major Competitors' Net Income Growth (Numerical Representation)

\begin{tabular}{|l|r|r|r|r|r|r|}
\hline Net Income (in billions) & 2016 Q1 & 2017 Q1 & 2018 Q1 & 2019 Q1 & 2020 Q1 & 2020 Q4 \\
\hline Microsoft & 10.48 & 24.28 & 15.77 & 34.93 & 46.27 & 51.31 \\
\hline Apple & 50.68 & 45.73 & 53.32 & 57.17 & 57.22 & 63.93 \\
\hline Alphabet & 16.52 & 20.70 & 16.64 & 27.99 & 34.52 & 40.27 \\
\hline Oracle & 8.84 & 8.92 & 3.66 & 10.62 & 10.76 & 10.38 \\
\hline IBM & 12.88 & 11.61 & 5.68 & 8.64 & 9.02 & 5.59 \\
\hline
\end{tabular}




\section{Comparing Total Liabilities and Shareholders Equity:}

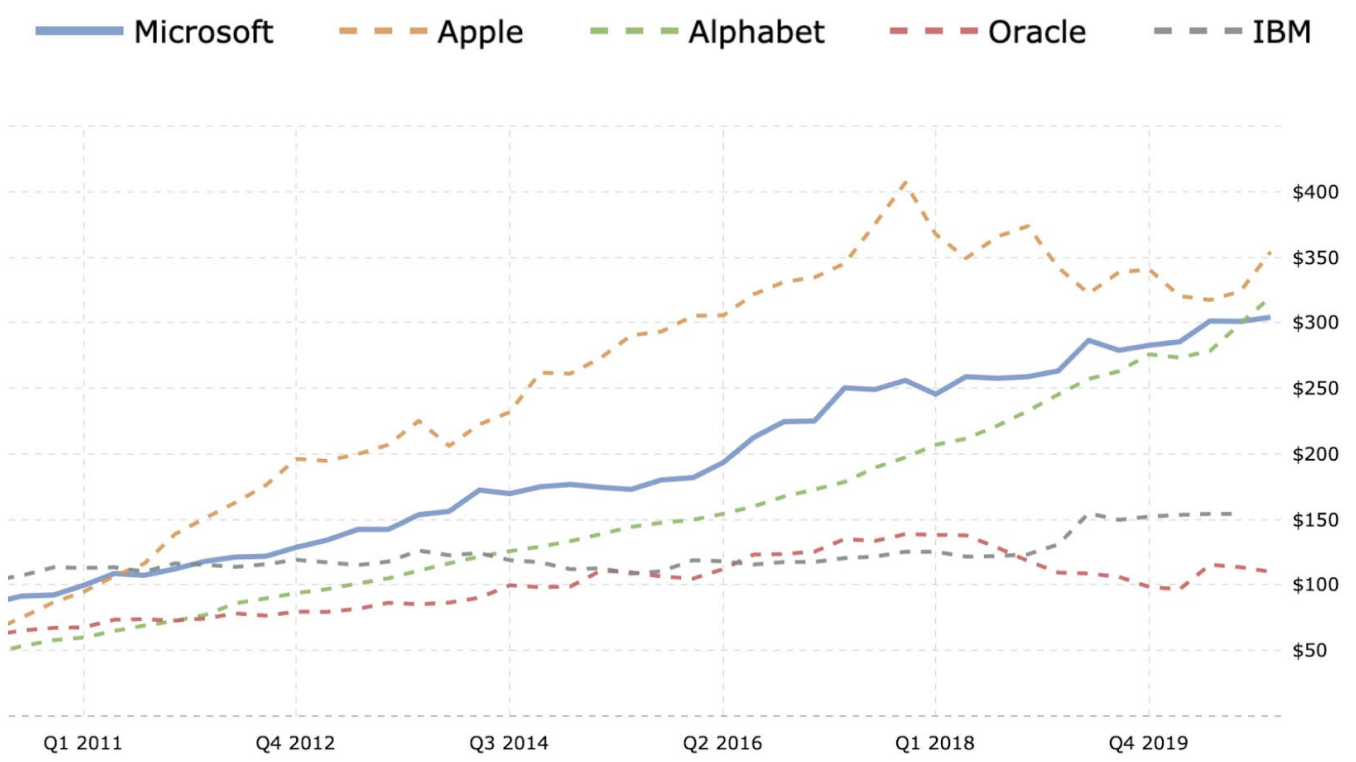

Figure 10: Microsoft Corporation's And Its Major Competitors' Total Liabilities and Shareholders Equity Growth (Graphical Representation)

Table 4: Microsoft Corporation's And Its Major Competitors' Total Liabilities and Shareholders Equity Growth (Numerical Representation)

\begin{tabular}{|l|r|r|r|r|r|r|}
\hline Total Liabilities \& Shareholders Equity (in billions) & 2016 Q1 & 2017 Q1 & 2018 Q1 & 2019 Q1 & 2020 Q1 & 2020 Q4 \\
\hline Microsoft & 181.87 & 225.02 & 245.50 & 263.28 & 285.45 & 304.14 \\
\hline Apple & 305.28 & 334.53 & 367.50 & 342.00 & 320.40 & 354.05 \\
\hline Alphabet & 149.75 & 172.76 & 206.94 & 245.35 & 273.40 & 319.62 \\
\hline Oracle & 104.89 & 125.38 & 138.20 & 109.44 & 96.70 & 110.01 \\
\hline IBM & 118.86 & 117.50 & 125.29 & 130.93 & 153.40 & 154.13 \\
\hline
\end{tabular}




\section{Comparing Gross Margins:}

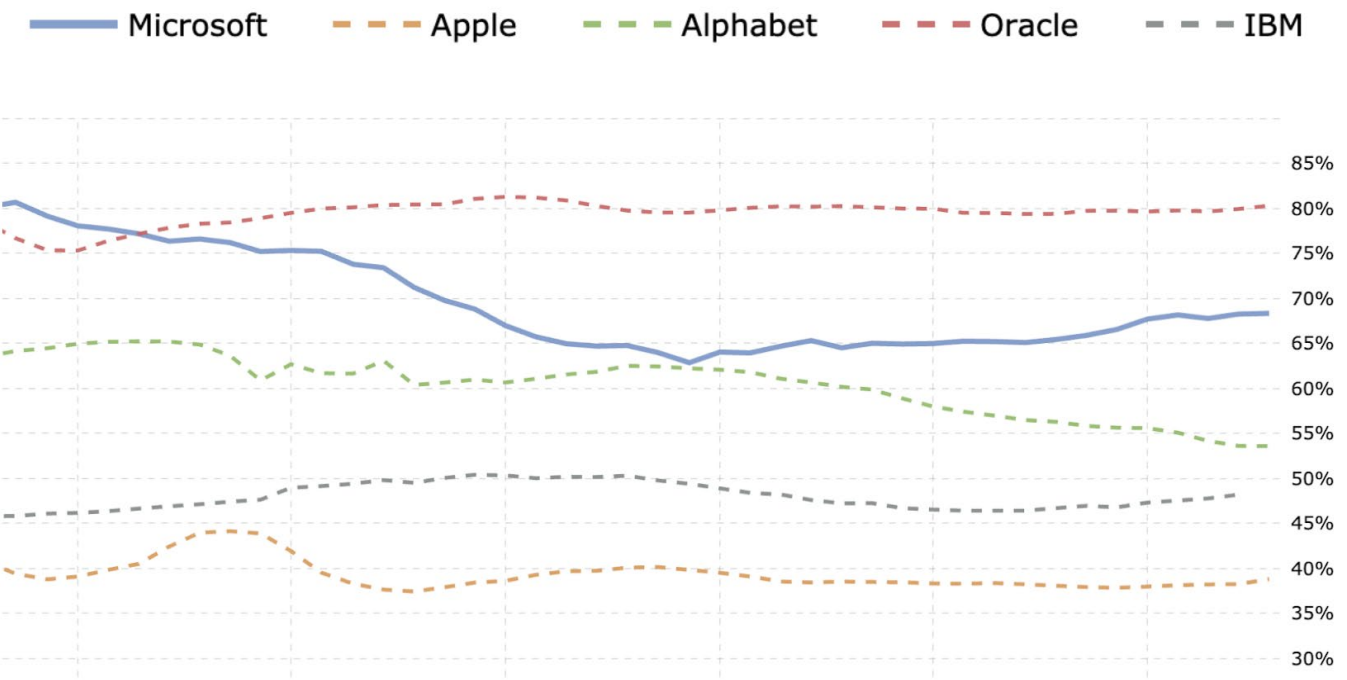

$\begin{array}{llllll}\text { Q1 } 2011 & \text { Q4 } 2012 & \text { Q3 } 2014 & \text { Q2 } 2016 & \text { Q1 } 2018 & \text { Q4 } 2019\end{array}$

Figure 11: Microsoft Corporation's And Its Major Competitors' Gross Margin Growth (Graphical Representation)

Table 5: Microsoft Corporation's And Its Major Competitors' Gross Margin Growth (Graphical Representation)

\begin{tabular}{|l|r|r|r|r|r|r|}
\hline Gross Margin (\%) & 2016 Q1 & 2017 Q1 & 2018 Q1 & 2019 Q1 & 2020 Q1 & 2020 Q4 \\
\hline Microsoft & 62.86 & 65.32 & 64.99 & 65.44 & 68.17 & 68.35 \\
\hline Apple & 39.81 & 38.41 & 38.30 & 38.05 & 38.11 & 38.78 \\
\hline Alphabet & 62.23 & 60.66 & 57.99 & 56.28 & 55.08 & 53.58 \\
\hline Oracle & 79.56 & 80.22 & 79.99 & 79.42 & 79.80 & 80.33 \\
\hline IBM & 49.38 & 47.58 & 46.52 & 46.68 & 47.52 & 48.18 \\
\hline
\end{tabular}

Microsoft $\quad---$ Apple $\quad---$ Alphabet $\quad--$-Oracle $\quad---$ IBM

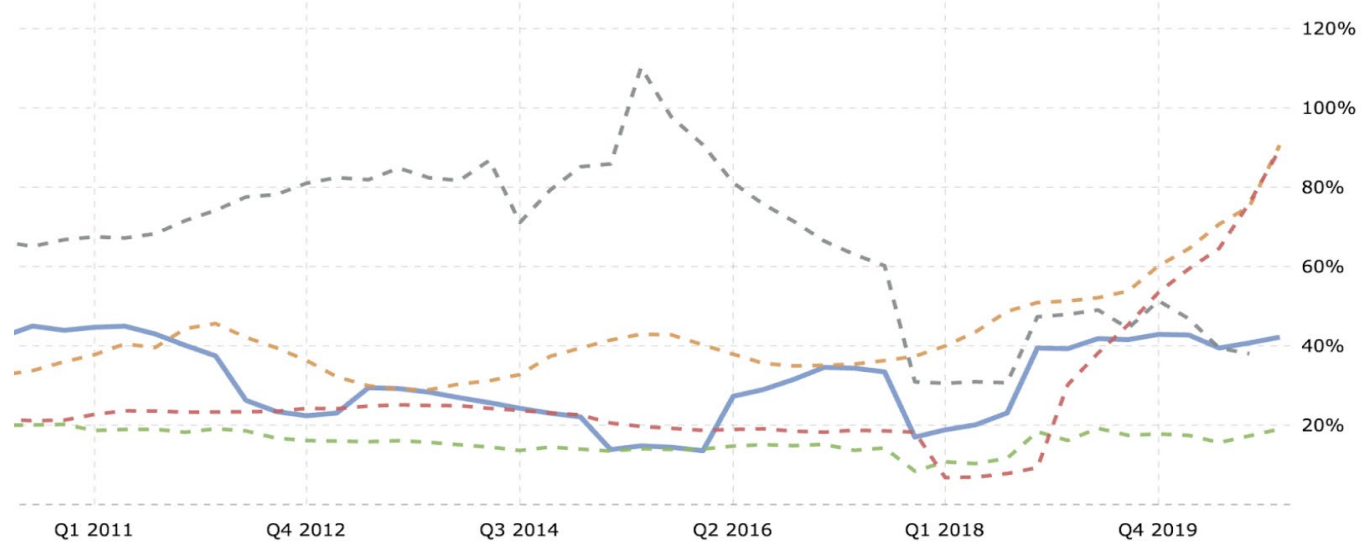

Figure 12: Microsoft Corporation's And Its Major Competitors' Return on Equity (ROE) Growth (Graphical Representation) 
Table 6: Microsoft Corporation's And Its Major Competitors' Return on Equity (ROE) Growth (Numerical Representation)

\begin{tabular}{|l|r|r|r|r|r|r|}
\hline Return on Equity (\%) & 2016 Q1 & 2017 Q1 & 2018 Q1 & 2019 Q1 & 2020 Q1 & 2020 Q4 \\
\hline Microsoft & 13.56 & 34.58 & 18.83 & 39.28 & 42.74 & 42.19 \\
\hline Apple & 40.24 & 35.09 & 39.97 & 51.29 & 64.49 & 90.59 \\
\hline Alphabet & 14.00 & 15.16 & 10.76 & 16.16 & 17.43 & 19.03 \\
\hline Oracle & 18.69 & 18.25 & 6.80 & 30.18 & 59.40 & 89.57 \\
\hline IBM & 90.70 & 66.44 & 30.58 & 47.93 & 46.84 & 38.03 \\
\hline
\end{tabular}

Microsoft $\quad-=-$ Apple $\quad-=-$ Alphabet $\quad-=-$ Oracle $\quad-=-$ IBM

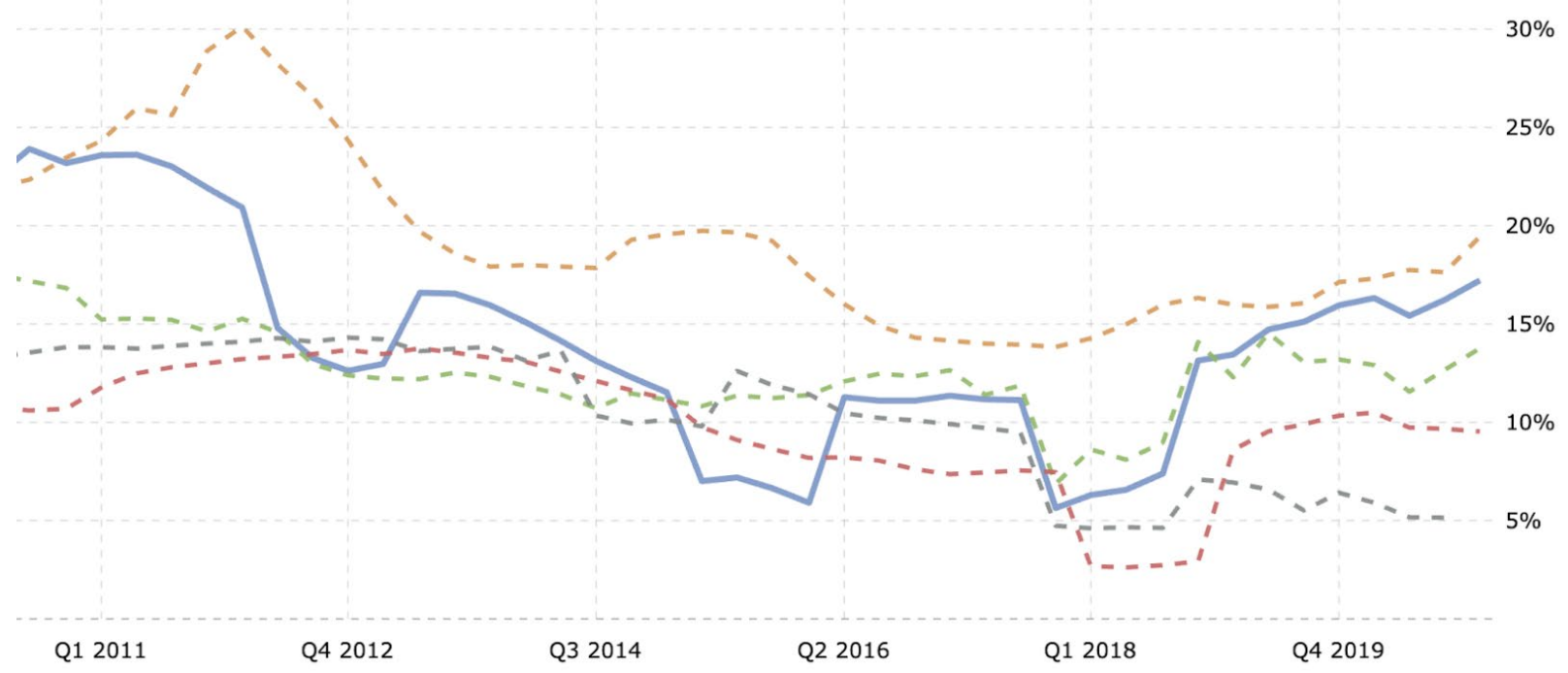

Figure 13: Microsoft Corporation's And Its Major Competitors' Return on Assets (ROA) Growth (Graphical Representation)

Table 7: Microsoft Corporation's And Its Major Competitors' Return on Equity (ORE) Growth (Numerical Representation)

\begin{tabular}{|l|r|r|r|r|r|r|}
\hline Return on Assets (\%) & 2016 Q1 & 2017 Q1 & 2018 Q1 & 2019 Q1 & 2020 Q1 & 2020 Q4 \\
\hline Microsoft & 5.91 & 11.35 & 6.30 & 13.45 & 16.32 & 17.22 \\
\hline Apple & 17.44 & 14.15 & 14.27 & 15.98 & 17.31 & 19.44 \\
\hline Alphabet & 11.39 & 12.65 & 8.62 & 12.29 & 12.91 & 13.76 \\
\hline Oracle & 8.19 & 7.36 & 2.68 & 8.60 & 10.49 & 9.53 \\
\hline IBM & 11.43 & 9.91 & 4.61 & 6.94 & 5.91 & 5.15 \\
\hline
\end{tabular}




$$
\text { Microsoft = = - Apple = - - Alphabet = - - Oracle = - - IBM }
$$

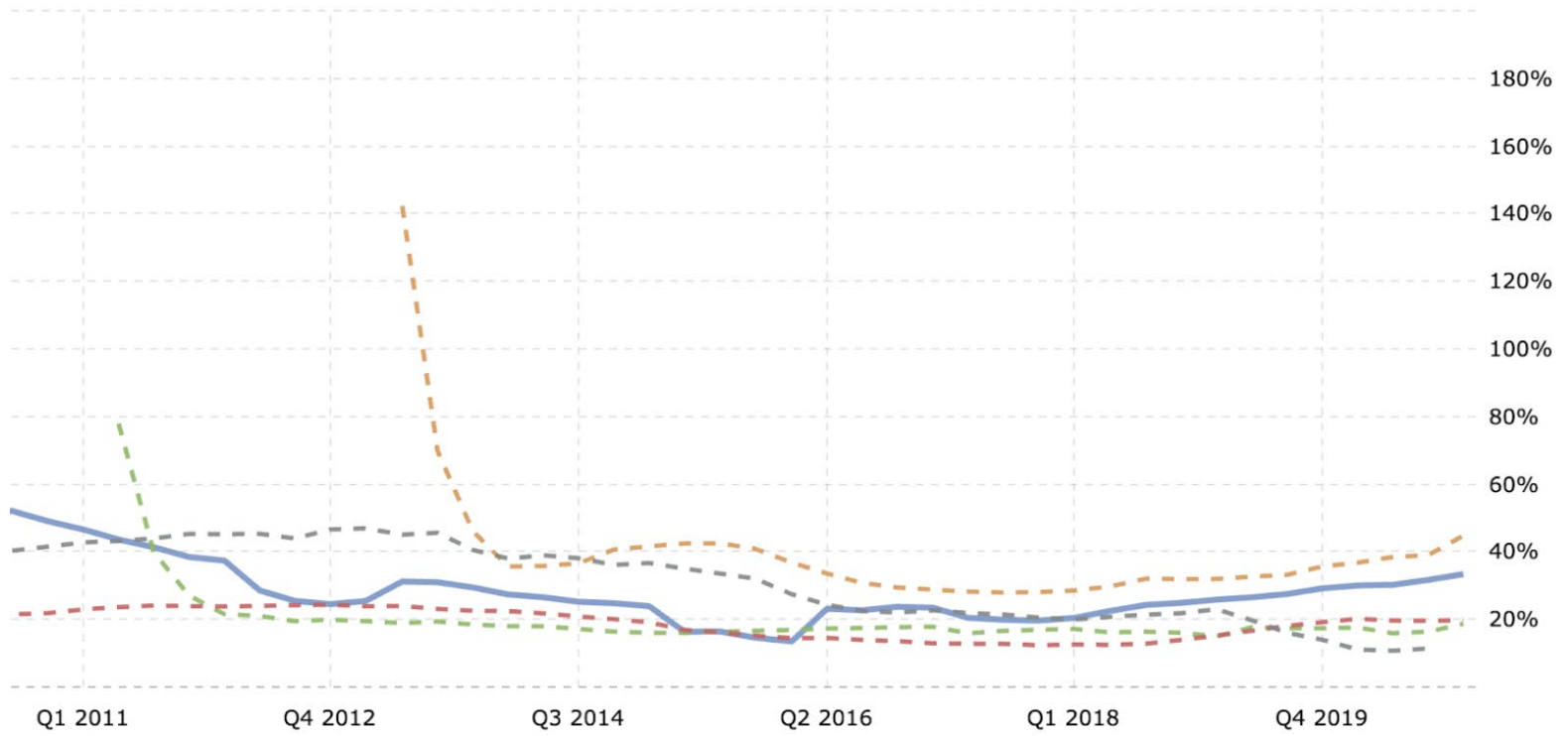

Figure 14: Microsoft Corporation's and Its Major Competitors' Return on Investment (ROI) Growth (Graphical Representation)

Table 8: Microsoft Corporation's and Its Major Competitors' Return on Investment (ROI) Growth (Graphical Representation)

\begin{tabular}{|l|r|r|r|r|r|r|}
\hline Return on Investment (\%) & 2016 Q1 & 2017 Q1 & 2018 Q1 & 2019 Q1 & 2020 Q1 & 2020 Q4 \\
\hline Microsoft & 13.49 & 23.45 & 20.41 & 25.83 & 30.02 & 33.37 \\
\hline Apple & 36.78 & 28.81 & 28.54 & 31.95 & 36.76 & 44.77 \\
\hline Alphabet & 16.87 & 17.82 & 17.17 & 14.95 & 17.58 & 18.67 \\
\hline Oracle & 14.45 & 12.94 & 12.56 & 15.16 & 20.15 & 19.76 \\
\hline IBM & 27.42 & 22.67 & 19.93 & 22.99 & 11.09 & 11.38 \\
\hline
\end{tabular}

\section{Conclusion}

According to the company's financial analysis and its development in comparison with its major competitors in the technology industry, Microsoft Corporation is booming in spite of the coronavirus pandemic. With the drastic shift to a digital-first world, the company has created a surge in demand for its services, causing its stock to rally. As more people continue to be locked down, this situation has resulted in higher demand for digital services that at the same time created a virtuous cycle for their revenues. This ended up with an improved stock market performance in Microsoft Corporations and the entire technology industry.

\section{Acknowledgments}

I would like to thank Columbia University Academic Year Immersion Program Admissions Office for giving me admission to the pre-college course "Introduction to Business, Economics, and Finance" from which I acquired the necessary knowledge to conduct this academic research and financial analysis on Microsoft Corporation. I would also 
like to thank Thomas W. Leach, a Columbia University professor, due to his support and guidance during the development of this entire project.

\section{References}

Microsoft Corporation. (2020, July). July 30, 2020 - 10-K: Annual report for the year ending June 30, 2020. U.S. Securities and Exchange Commission.

https://www.sec.gov/Archives/edgar/data/789019/000156459020034944/msft10k 20200630.htm\#ITEM 6 SELECTED FINANCIAL DATA.

NasdaqGS. (2021, January 29). Microsoft Corporation (MSFT). Yahoo Finance.

https://finance.yahoo.com/quote/MSFT?p=MSFT\&.tsrc=fin-srch.

MacroTrends. (n.d.). Microsoft - 35 Year Stock Price History | MSFT. Retrieved May 24, 2021, from https://www.macrotrends.net/stocks/charts/MSFT/microsoft/stock-price-history. 